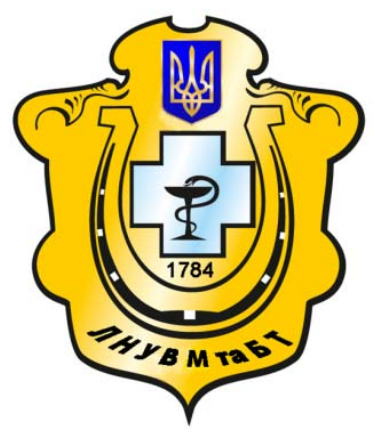

Науковий вісник Львівського національного університету ветеринарної медицини та біотехнологій імені С.З. Гжицького

Scientific Messenger of Lviv National University of Veterinary Medicine and Biotechnologies named after S.Z. Gzhytskyj

doi:10.15421/nvlvet7524

ISSN 2519-268X print

ISSN 2518-1327 online

http://nvlvet.com.ua/

УДК 637.146 : $579.67: 613.2$

\title{
Вплив вівсяного борошна на технологічні властивості йогурту
}

\author{
Ю.В. Назаренко, Л.М. Кітченко, С.О. Окуневська, В.В. Цигура \\ Сумський національний аграрний університет, \\ вул. Г. Кондратьєва, 160, м.Суми, 40021,Украӥна
}

nazarenko.sumy@gmail.com, lyudmila_kitchenko@ukr.net, snau-okunevska@ukr.net, viktoriya.cigura@mail.ru

\begin{abstract}
В роботі наведені результати дослідження зразків молочних сумішей з вівсяним борошном з метою підбору раціональних параметрів виробництва та коректування технологічних режимів. Для вирімення проблеми оптимального збалансованого харчування необхідні розробка та впровадження у виробництво продуктів заданого складу (високобілкові, високовуглеводні, вуглеводно-мінеральні та ін.), які повинні сприяти підвищенню працездатності, відновленню організму, забезпеченню необхідними нутрієнтами. Сучасні технологї виробництва харчових продуктів включають використання різних добавок для поліпшення технологічних параметрів продуктів, а також сенсорних і текстурних характеристик. Охарактеризовано властивості вівсяного борошна як унікального інгредієнта в плані набору вітамінів, мікроелементів, амінокислот, солей, ферментів, ефірних масел, жирів, вуглеводів. Наведено дочільність використання інгредієнтів рослинного походження як стабілізаторів структури продуктів харчування. Постановка експерименту базується на класичній технологічній схемі виробництва йогурту з незначними змінами. Описані основні технологічні операції виробництва з зазначенням параметрів процесів. На підставі досліджень обтрунтовано та розроблено рецептури йогурту з різною масовою часткою вівсяного борошна, проведено порівняння зі зразком, аналогом. Фізико-хімічні, мікробіологічні дослідження проводили за допомогою загальноприйнятих методик, органолептичні - дегустачійним методом, комісією в складі 6 осіб. Проведена порівняльна характеристика фізико-хімічних властивостей та якості отриманих згустків. Експериментально встановлена оптимальна масова частка вівсяного борошна в йогурті. Вивчено вплив технологічних факторів на якість продукту, встановлена залежність часу сквашування від масової частки внесеної вівсяної муки. Вдосконалена технологія вироблення йогурту з вівсяним борошном шляхом розробки нової рецептури і зменшення терміну сквашування за рахунок внесення вівсяної муки як стабілізаційної системи.
\end{abstract}

Ключові слова: технологічні параметри, кисломолочні продукти, йогурт, вівсяна мука, стабілізатор, фізико-хімічні властивості, кислотність, згусток.

\section{Влияние овсяной муки на технологические свойства йогурта}

Ю.В. Назаренко, Л.Н. Китченко, С.О. Окуневская, В.В. Цигура

nazarenko.sumy@gmail.com, lyudmila_kitchenko@ukr.net, snau-okunevska@ukr.net, viktoriya.cigura@mail.ru

Сумской национальный аграрный университет,

ул. Г. Кондратьева, 160, г. Сумьи, 40021, Украина

В работе приведены результаты исследования образиов молочных смесей с овсяной мукой с иелью подбора оптимальных параметров производства и корректировки технологических режимов. Современные технологии производства пищевых продуктов включают использование различных добавок для улучшения технологических параметров продуктов, а также сенсорных и текстурных характеристик. Охарактеризованы свойства овсяной муки как уникального ингредиента в плане набора витаминов, микроэлементов, аминокислот, солей, ферментов, эфирных масел, жиров, углеводов. Приведены иелесообразность использования ингредиентов растительного происхождения в качестве стабилизаторов структуры продуктов питания. Постановка эксперимента базируется на классической технологической схеме производства йогурта

Citation:

Nazarenko, J.V., Kitchenko, L.N., Okunevska, S.O., Tsyhura, V.V. (2017). The influence of oatmeal on technological characteristics of yogurt. Scientific Messenger LNUVMBT named after S.Z. Gzhytskyj, 19(75), 120-123. 
с незначительными изменениями. Описаны основные технологические операции производства с указанием параметров процессов. На основании исследований обосновань и разработань рецептуры йогурта с разной массовой долей овсяной муки, проведено сравнение с образиом-аналогом. Физико-химические, микробиологические исследования проводили с помощзью общепринятых методик, органолептические - дегустационным методом, комиссией в составе 6 человек.

Проведена сравнительная характеристика физико-химических свойств и качества полученных сгустков. Экспериментально установлена оптимальная массовая доля овсяной муки в йогурте. Изучено влияние технологических факторов на качество продукта, установлена зависимость времени сквашивания от массовой доли внесенной овсяной муки. Усовериенствована технология выработки йогурта с овсяной мукой путем разработки новой рецептуры и уменьшения срока сквашивания за счет внесения овсяной муки как стабилизационной системы.

Ключевые слова: технологические параметры, кисломолочные продукты, йогурт, овсяная мука, стабилизатор, физико-химические свойства, кислотность, сгусток.

\title{
The influence of oatmeal on technological characteristics of yogurt
}

\author{
J.V. Nazarenko, L.N. Kitchenko, S.O. Okunevska, V.V. Tsyhura \\ nazarenko.sumy@gmail.com, lyudmila_kitchenko@ukr.net, snau-okunevska@ukr.net, viktoriya.cigura@mail.ru \\ Sumy National Agrarian University, \\ G. Kondratiev Str., 160, Sumy, 40021, Ukraine
}

\begin{abstract}
The work presents the results of milk mixtures research samples with oat flour, aimed to select rational parameters for production and technological adjustment modes. To solve the problem of optimal balanced diet requires the development and introduction of a given composition into manufacturing (High - protein, high - carbohydrate, carbohydrate - mineral, etc.), which should help to increase efficiency, recovery of the body, providing necessary nutrients. Modern technologies of food production include the use of various additives to improve the technical parameters of products, sensory and textural characteristics. Such additives are used: modified starch, gums, dietary fiber, etc. Recently, gaining popularity stabilizers of natural origin. On which there was no impact to chemical treatment and modification. Just such is oat flour. The properties of oat flourare characterized, as a unique ingredient in terms of a set of vitamins, minerals, amino acids, salts, enzymes, essential oils, fats, carbohydrates.

An appropriateness of herbal ingredients as stabilizers of food structures. Setting the experiment is based on the classical technological scheme of yogurt production with minor changes. The basic process steps show the manufacturing process parameters. Based on research proved and developed: yogurt recipes with different mass fraction of oat flour, a comparison with a sample analog. Physical-chemical, microbiological studies were performed using conventional techniques, organoleptical - tasting method by 6 people commission. Comparative characteristics of physical and chemical properties and quality of obtained clusters has been held. The optimum mass fraction of oat flour in yogurt has been experimentally estimated. The influence of technological factors on product quality has been studied, the dependence of the fermentation time on mass fraction of added oat flour. Production of yogurt with oat flour has been enhanced by developing new recipes and reduction of fermentation by making oat flour as stabilizing system.
\end{abstract}

Key words: technological parameters, dairy products, yogurt, oat flour, stabilizer, physical-chemical properties, acidity, clot.

\section{Вступ}

Йогурт являє собою кисломолочний продукт, що користується високою популярністю і володіє високою поживною цінністю. Сучасні технології виробництва харчових продуктів дозволяють використовувати різні добавки для поліпшення технологічних параметрів продуктів, а також сенсорних і текстурних характеристик.

Численними дослідженнями доведено взаємнопозитивний ефект від комбінування тваринних та рослинних компонентів у продуктах харчування. Їх поєднання дозволяє доповнювати продукти відсутніми біологічно активними речовинами. До того ж, компоненти рослинного походження вводять до рецептури кисломолочних напоїв, зокрема йогуртів, в як стабілізатори та структуроутворювачі (Dyadechko and Bakhmach, 2002; Morhun et al., 2010). Великою популярністю серед виробників користуються модифіковані крохмалі, камеді, харчові волокна. Вони практично не впливають на смакові якості продукту (мають нейтральний смак та аромат), забезпечують високі стабілізаційні показники, але не приносять нічого корисного для споживача.

Останнім часом набирають популярності стабілізатори із натуральної рослинної сировини, не піддані хімічній обробці та модифікаціям, тому як стабілізатор було обрано вівсяне борошно (Dyadechko and Bakhmach, 2002).

Вітчизняними та закордонними науковцями встановлено, що вісяне борошно у сквашеному продукті виконує функції структуроутворювача дисперсної системи, речовини-збагачувача вуглеводами, білками, вітамінами і забезпечує молочнокислі мікроорганізми поживними речовинами для росту i розвитку (Dyadechko and Bakhmach, 2002; Antipova et al., 2012).

Вівсяне борошно є природним джерелом вітамінів E, РР, групи В, а також макро- і мікроелементів: Калію, Кальцію, Фосфору, Магнію, Натрію, Заліза, Марганецю та ін. В цільнозерновому вівсяному борошні існує 2 види клітковини - розчинна і нерозчинна (Zaharova, 2005).

Метою роботи було дослідження впливу вівсяного борошна на технологічні властивості йогурту.

\section{Матеріал і методи досліджень}

Для експериментальних досліджень було складено 3 експериментальні зразки 3 внесенням вівсяного борошна 5, 10 та 15\%, за контроль було обрано йогурт класичний без цукру та наповнювачів. 
Дослідні зразки йогурту виготовлялися за традиційною технологією (Stepanova, 1999), вівсяне борошно перед внесенням в основну частину нормалізованої молочної суміші підготовлялося шляхом змішування 3 молоком 1:5 при температурі $10 \ldots 12{ }^{\circ} \mathrm{C}$ та перемішуванням протягом 30 хвилин.

Пастеризацію молочної суміші з вівсяним борошном проводили при температурі $95 \ldots 97^{\circ} \mathrm{C}$ з витримкою 10 с $з$ подальшим охолоджуванням до температури заквашування.

Для сквашування йогурту використовувалась закваска прямого внесення торгової марки Good Food. До складу закваски входять термофільні культури

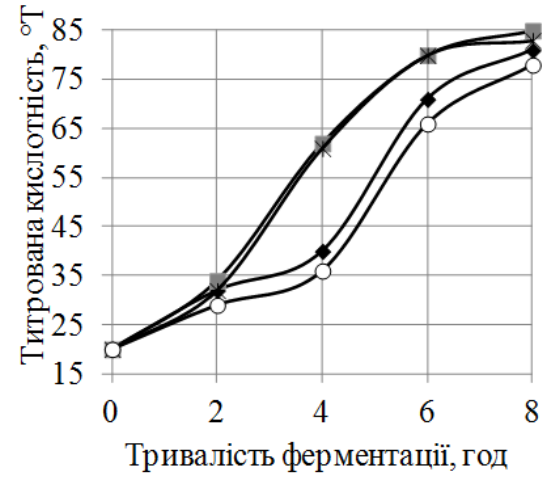

молочнокислих мікроорганізмів, а саме: Lactobacillus bulgaricus, Lactobacillus acidophillus, Streptococcus thermophillus. Оптимальна температура розвитку мікроорганізмів $-38 \ldots 42{ }^{\circ} \mathrm{C}$.

В процесі експериментального дослідження досліджували активність кислотоутворення в згустках за змінами активної (рис. 1, б) й титрованої кислотності (рис. 1, а).

При виконанні досліджень титровану кислотність зразків визначали титрометричним методом за ГОСТ 3624-92, активну кислотність - потенціометричним методом за ГОСТ 25754-85, температуру - за ГОСТ 25754-85.

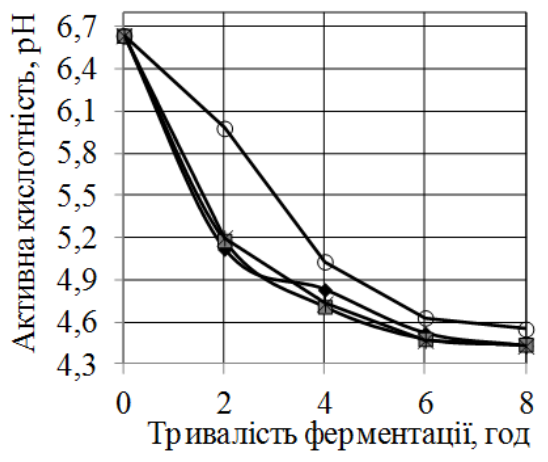

Зразок 1 -"-Зразок 2 *-3разок $3-0-$ Контрольний

Рис. 1. Зміна титрованої (а), активної (б) кислотності зразків у процесі ферментації

\section{Результати та їх обговорення}

Тривалість сквашування зразків 3 вівсяним борошном менша, ніж 3 контрольним зразком. Зразок 3 внесенням вівсяного борошна 5\% досягнув ізоелектричної точки на 5 годину ферментації, зразок з 10\% і 20\% вівсяного борошна на 4 годину, порівняно 3 контрольним зразком, що досяг ізоелектричного стану білків лише на 6-ту годину. Зменшення тривалості сквашування оберненопропорційне відсотку внесення вівсяного борошна.

В'язкість зразків мала прямопропорційну залежність, і збільшувалась зі збільшенням відсотка внесення вівсяного борошна в молочну суміш.

Також було досліджено органолептичні показники експериментальних зразків порівняно з контрольним.

Органолептичні показники дослідних зразків

\begin{tabular}{|l|c|c|c|}
\hline Назва зразка & \multicolumn{3}{|c|}{ Органолептичні показники } \\
\cline { 2 - 4 } & Смак та запах & Колір & Консистенція \\
\hline Контроль & $\begin{array}{c}\text { Чілий, рівномірний за всією } \\
\text { масою }\end{array}$ & $\begin{array}{c}\text { Однорідна, ніжна, характерна } \\
\text { даному виду продукту. }\end{array}$ \\
\hline Зразок 1 & $\begin{array}{c}\text { Чистий, кисломолочний з легким при- } \\
\text { смаком вівсяного борошна }\end{array}$ & $\begin{array}{c}\text { Білий з кремовим відтінком, } \\
\text { рівномірний за всією масою. }\end{array}$ & $\begin{array}{c}\text { Однорідна, ніжна, характерна } \\
\text { даному виду продукту }\end{array}$ \\
\hline Зразок 2 & $\begin{array}{c}\text { Кисломолочний з невираженим запа- } \\
\text { хом і присмаком вівсяного борошна }\end{array}$ & $\begin{array}{c}\text { Світло-кремовий, однорідний } \\
\text { за всією масою }\end{array}$ & Однорідна, надмірно в’язка \\
\hline Зразок 3 & $\begin{array}{c}\text { Кисломолочний з вираженим запахом і } \\
\text { присмаком вівсяного борошна }\end{array}$ & $\begin{array}{c}\text { Світло-кремовий, однорідний } \\
\text { за всією масою }\end{array}$ & $\begin{array}{c}\text { Однорідна, дуже в’язка, не } \\
\text { властива для йогурту }\end{array}$ \\
\hline
\end{tabular}

Аналізуючи дані таблиці, можна зробити висновок, що збільшення масової частки вівсяного борошна понад 10\% призводить до зниження органолептичних показників кисломолочного напою: надмірно збільшується в'язкість, з'являється виражений запах і присмак рослинного інгредієнту. А зразок 1 з внесенням вівсяного борошна 5\% мав вищі органолептичні показники, тому для подальших досліджень було обрано зразок з масовою часткою вівсяного борошна $5 \%$.

Досліджено мікробіологічні показникі готових зразків продукту згідно $з$ ДСТУ 4343:2004 «Йогурт. Загальні технічні умови». 
Мікробіологічні показники зразків

\begin{tabular}{|c|c|c|c|c|c|}
\hline \multirow{2}{*}{ Назва показника } & \multirow{2}{*}{ Норма } & \multicolumn{4}{|c|}{ Показники зразків } \\
\hline & & Контроль & Зразок 1 & Зразок 2 & Зразок 3 \\
\hline $\begin{array}{l}\text { Кількість молочнокислих бактерій } \\
\text { КУО в } 1 \text { cм }^{3} \text {, не менше ніж }\end{array}$ & $1 \times 10^{7}$ & $2 \ldots .5 \times 10^{8}$ & $3 \ldots 7 \times 10^{8}$ & $6 \ldots 8 \times 10^{8}$ & $7 \ldots 9 \times 10^{7}$ \\
\hline $\begin{array}{l}\text { Бактерії групи кишкових паличок } \\
\text { (коліформи), в } 0,1 \mathrm{~cm}^{3}\end{array}$ & Не дозволено & \multicolumn{4}{|c|}{ Не виявлено } \\
\hline Дріжджі, КУО в 1 см3, не більше ніж & 50 & 4 & 9 & 12 & 30 \\
\hline $\begin{array}{l}\text { Плісеневі гриби, КУО в } 1 \text { см3, не бі- } \\
\text { льше ніж }\end{array}$ & 50 & Не виявлено & 3 & 9 & 15 \\
\hline
\end{tabular}

3 таблиці видно, що отримані мікробіологічні показники всіх зразків відповідають вимогам ДСТУ 4343:2004. Наявність молочнокислих мікроорганізмів у кількості $10^{8}$ може свідчити про те, що разом із оптимальною температурою сквашування наявність вівсяного борошна не призводить до негативного впливу на ріст і розвиток молочнокислих мікроорганізмів.

\section{Висновки}

В результаті проведених експериментальних досліджень обгрунтована раціональна масова частка внесення вівсяного борошна у технології виробництва йогурту. Досліджено закономірність процесу ферментації молочних сумішей з вівсяним борошном. Досліджені фізико-хімічні, мікробіологічні та органолептичні параметри зразків. Обрано зразок для подальших досліджень 3 внесенням вівсяного борошна $5 \%$.

Перспективи подальших досліджень:

- обгрунтування параметрів зберігання йогуртів 3 вівсяним борошном;

- розробка рецептур та технологій виробництва йогуртів 3 вівсяним борошном із фруктовими наповнювачами.

\section{Бібліографічні посилання}

Morhun, V., Zhyhunov, D., Kroshko, O. (2010). Vysoka kharchova tsinnist' kompozytsiynykh sumishey $\mathrm{Z}$ boroshna riznykh zernovykh. Zerno i khlib. 3, 39 (in Ukrainian).

Dyadechko, O.V., Bakhmach, V.A. (2002). Stabilizatory roslynnoho pokhodzhennya dlya mayoneznykh emul'siy. Suchasni problemy tovaroznavstva: Zb. nauk. prats'. K., 229-231 (in Ukrainian).

Antipova, L.V., Morkovkina, I.A., Popov, V.I. (2012). Ispolzovanie molochnogo i rastitelnogo syirya kak osnovyi dlya funktsionalnyih napitkov. Izvestiya VUZov. Pischevaya tehnologiya. 2-3, 79-83 (in Russian).

Zaharova, L.M. (2005). Kislomolochnyie belkovyie produktyi s zernovyimi dobavkami. Molochnaya promyishlennost. 5, 62-63 (in Russian).

Stepanova, L.I. (1999). Spravochnik tehnologa molochnogo proizvodstva. Tehnolo-gii i receptury. Tom 1 Cel'nomolochnie produkti. St. Petersburg: GIORD (in Russian).

Стаття надійшла до редакиї̈ 24.02.2017 